\title{
Population trends of the Kuril harbour seal Phoca vitulina stejnegeri from 1974 to 2010 in southeastern Hokkaido, Japan
}

\author{
Yumi Kobayashi ${ }^{1 *}$, Tatsuya Kariya ${ }^{2}$, Jun Chishima ${ }^{2}$, Kei Fujii ${ }^{2}$, Kazuo Wada ${ }^{3}$, Shinya Baba ${ }^{1}$, \\ Tetsuro Itoo ${ }^{4, \mp}$, Toshiyasu Nakaoka ${ }^{5}$, Miki Kawashima ${ }^{2}$, Sachiko Saito ${ }^{2}$, Noriyuki Aoki ${ }^{6}$, \\ Shin-ichi Hayama ${ }^{7}$, Yuichi Osa ${ }^{8}$, Hidemi Osada ${ }^{2}$, Akio Niizuma ${ }^{9,7}$, Masatsugu Suzuki ${ }^{10}$, \\ Yohjiro Uekane $^{2, \mathrm{I}}$, Kei Hayashi ${ }^{11}$, Mari Kobayashi ${ }^{12,13}$, Noriyuki Ohtaishi ${ }^{14}$, Yasunori Sakurai ${ }^{1}$ \\ ${ }^{1}$ Graduate School of Fisheries Sciences, Hokkaido University, Hakodate, Hokkaido 041-8611, Japan \\ ${ }^{2}$ Pinniped Research Group, Sapporo, Hokkaido 005-0018, Japan \\ ${ }^{3}$ Primate Research Institute of Kyoto University, Inuyama, Aichi 484-8506, Japan \\ ${ }^{4}$ North Pacific Pinniped Research Association, Gifu 501-1193, Japan \\ ${ }^{5}$ Erimo Town Museum, Erimo, Hokkaido 058-0203, Japan \\ ${ }^{6}$ Japanese Bird Banding Association, Nemuro, Hokkaido, 087-0036, Japan \\ ${ }^{7}$ Center for Wildlife Conservation and Management, Nippon Veterinary and Animal Science University, Tokyo 180-8602, Japan \\ ${ }^{8}$ Environmental and Geological Research Department, Institute of Environmental Sciences, Hokkaido Research Organization, \\ Kushiro, Hokkaido 085-8588, Japan \\ ${ }^{9}$ Faculty of Human and Social Studies, Keisen University, Tokyo 206-8586, Japan \\ ${ }^{10}$ Department of Veterinary Medicine, Faculty of Applied Biological Sciences, Gifu University, Gifu 501-1193, Japan \\ ${ }^{11}$ Kuril Harbour Seal Research Group, Obihirio University of Agriculture and Veterinary Medicine, Obihiro, \\ Hokkaido 080-0835, Japan \\ ${ }^{12}$ Department of Aqua-Bioscience and Industry, Faculty of Bioindustry, Tokyo University of Agriculture, Abashiri, \\ Hokkaido 099-2493 Japan \\ ${ }^{13}$ Marine Wildlife Center of Japan, Incorporated Non Profit Organization, Abashiri, Hokkaido 093-0042, Japan \\ ${ }^{14}$ The Hokkaido University Museum, Sapporo, Hokkaido 060-0812, Japan
}

\begin{abstract}
The Kuril harbour seal Phoca vitulina stejnegeri is an endangered species which inhabits southeastern Hokkaido, Japan. Its population declined precipitously from between 1500 and 4800 individuals in the 1940s to a few hundred individuals in the early 1970s. The causes of this decline are thought to be commercial harvesting, bycatch in autumn set-net salmon fishing, and other human activities, including coastal fisheries. To quantify Kuril seal population trends, counts were performed each year at haul-out sites during the pupping season from 1974 to 2010 and during the moulting season from 1983 to 2010 . The average population growth rate was $\sim 4 \%$ per annum over the past 37 yr. Two haul-out sites (Kenbokki Island and Hattaushi) from which the species had disappeared in the early 1980s showed no evidence of being recolonized. Commercial harvesting ended in the late 1980s and probably had an effect on population trends until the 1990s. The bycatch of seals during autumn set-net salmon fishing in the 2000s remained similar to, or slightly greater than, that during the 1980s. Recently, seals have been observed at 9 haul-out sites during the pupping/moulting season along the coast of southeastern Hokkaido. Approximately $70 \%$ of the seals found were at Cape Erimo ( 500 seals) and at Daikoku Island and Akkeshi ( 250 seals).
\end{abstract}

KEY WORDS: Population counts · Bayesian state-space models · Conservation · Pinnipeds · Endangered species · Japan 


\section{INTRODUCTION}

For effective management and conservation of marine mammals, population trends and abundance estimates are needed. These trends are affected by interactions between marine mammals and fisheries, the effects of global climate change, and other anthropogenic effects on the environment (e.g. Alaska Sea Grant 1993, Anderson \& Piatt 1999).

The harbour seal Phoca vitulina is a widespread pinniped species (e.g. Shaughnessy \& Fay 1977, Jefferson et al. 1993). Harbor seals remain in coastal regions all year and come ashore only on specific shore reefs (Naito \& Nishiwaki 1972). They use haul-out sites for resting, pupping, and moulting (Bigg 1969, 1981, Niizuma 1986). Generally, the number of hauledout seals peaks during the pupping and moulting seasons, thereby providing the opportunity to perform population counts at these times of the biological cycle (e.g. Jeffries et al. 2003, Brown et al. 2005).

Currently, the harbour seal is classified into 5 subspecies (e.g. Burg et al. 1999, Westlake \& O'CorryCrowe 2002). The present worldwide population is estimated to be 350000 to 500000 animals, and the population is stable, classifying the seal as a species of 'Least Concern' using the IUCN (2012). However,

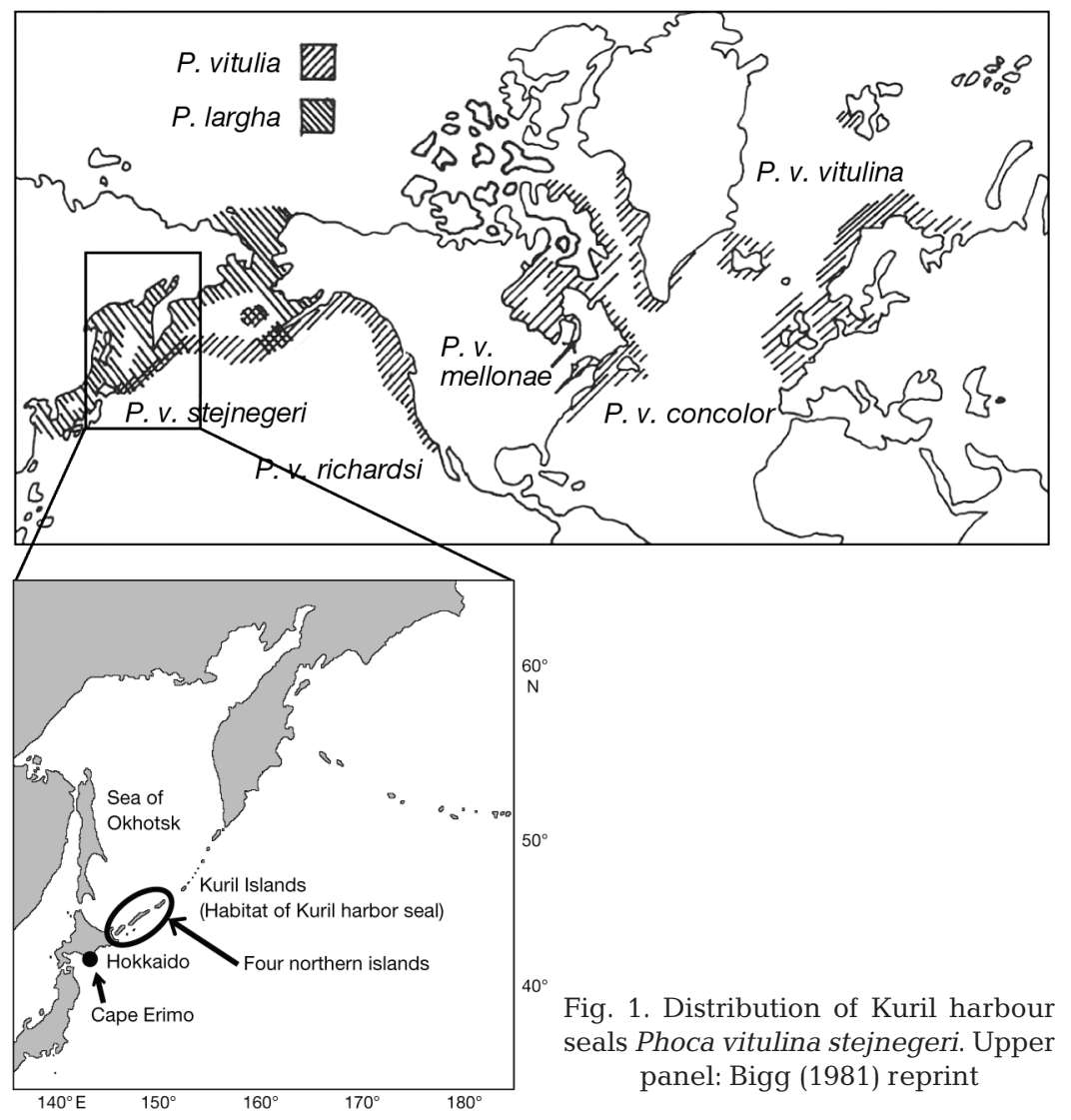

for conservation at a somewhat finer spatial scale, it is prudent to assess each of the subspecies separately, as some populations are small (IUCN 2012).

In the present article, we concentrate on 1 subspecies, Phoca vitulina stejnegeri (the Kuril harbour seal), distributed from the Commander Islands in Russia and the western Aleutian Islands in the USA to the eastern Pacific coast of Hokkaido, Japan (Niizuma \& Hayama 1986). The Kuril harbour seal was first discovered by Inukai (1942a,b), although the subspecies classification and distribution remain unclear. The Japanese name for the seals 'Zenigata azarashi' is used for $P$. V. stejnegeri distributed between southeastern Hokkaido, Japan, and the southern area of the Kuril Islands south to Cape Erimo (Niizuma \& Hayama 1986) (Fig. 1). Chyupakhina \& Panteleeva (1991) estimated the Kuril harbour seal population size to be 3000 throughout the Kuril Islands (including the Habomai Islands and Shikotan Island). Kuril harbour seals are distributed mainly among Habomai, Shikotan, Kunashiri, and Etorofu Islands - the 4 northern islands (Far East Pinniped Research Group 1993).

The population size of Kuril harbour seals along the southeastern coast of Hokkaido during the 1940s was between 1500 and 4800 (Itoo \& Shukunobe 1986). The population was estimated to be only a few hundred until the early $1970 \mathrm{~s}$; the causes of this decline are thought to be commercial harvesting of the seals and other human activities, including coastal fisheries (e.g. Itoo \& Shukunobe 1986, Hayama 1988).

In 1992, the Japanese Environment Agency assigned the Kuril harbour seal to 'Rank IB' (endangered species). In 2003, the seals were given legal protection under the Revised Birds and Mammals Protection Law (Japanese Ministry of the Environment Agency 2003). Thereafter, the Japanese Ministry of the Environment Agency was responsible for their protection and management. In 2012, the seals' status was modified to Rank 'II' (vulnerable species; Japanese Ministry of the Environment Agency 2012). In addition to this, the Japanese Fisheries Agency has designated the species 'vulnerable' (Japanese Fisheries Agency 2000).

In the present study, to estimate the population growth rate, assess the effects of hunting, and collate bycatch 
data on the Kuril harbour seal, we investigated the population status of Kuril seals in southeastern Hokkaido and also examined whether their haul-out sites have changed since the 1970s.

\section{MATERIALS AND METHODS}

\section{Study sites}

Population counts of Kuril harbour seals were conducted in southeastern Hokkaido (Niizuma et al. 1980, Itoo \& Shukunobe 1986). In Hokkaido, Japan, the Kuril harbour seal population has been divided into 2 maternal groups: the Cape Erimo population and the Eastern Hokkaido population (e.g. Fujii et al. 2006, 2007a,b, Nakagawa et al. 2010). The haul-out areas of the Cape Erimo population are concentrated in a small area of $\sim 2 \mathrm{~km}^{2}, \sim 200 \mathrm{~km}$ to the west of the more northeastern sites. For the Eastern Hokkaido population, there were 10 widely scattered haulout sites (Fig. 2, Supplement 1 at www.int-res.com/ articles/suppl/n024p061_supp.pdf).

In addition, we attempted to discover any new haulout sites using a questionnaire administered to the lo-

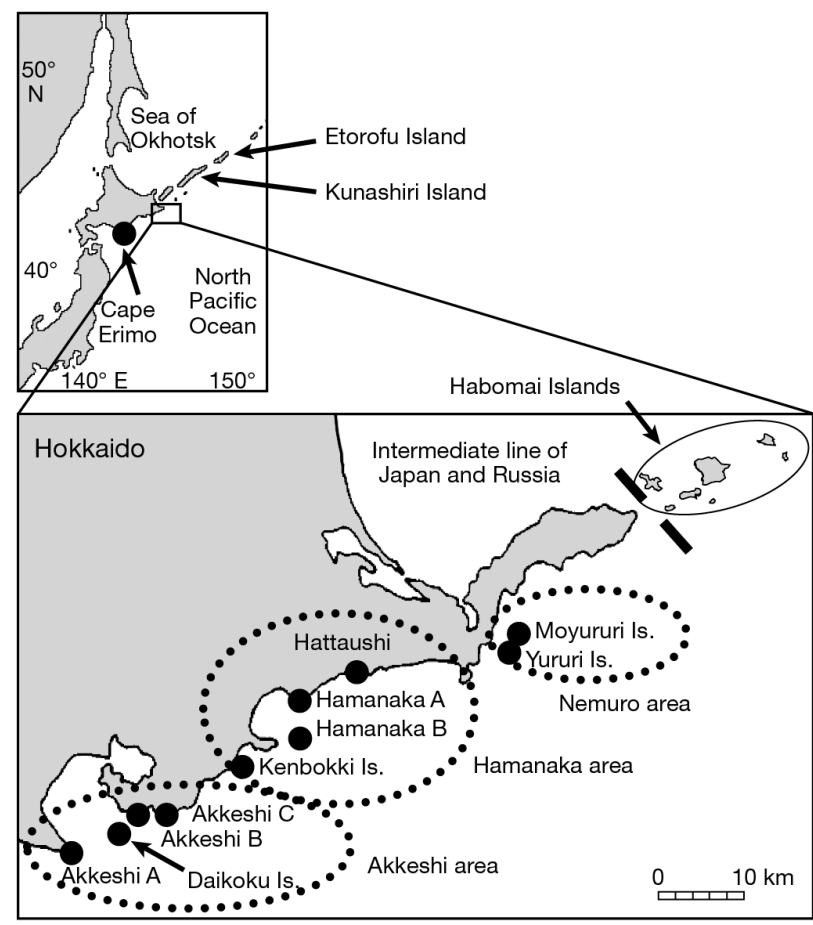

Fig. 2. Haul-out sites of Kuril harbour seals in southeastern Hokkaido, Japan. All haul-out sites are located on rocky shelves or ledges from the Nemuro Peninsula to Cape Erimo. Cape Erimo is the southern limit of the distribution of these seals, $\sim 200 \mathrm{~km}$ to the west of the easternmost sites cal people along the coastline from Nemuro Peninsula to Cape Erimo in 1984 and 1992. The coastline is readily accessible and easily traversed by researchers and coastal fishermen; therefore, it is unlikely that we would have missed new haul-out sites.

\section{Population counts}

To monitor the status of the Kuril harbour seal, population counts in the pupping season (May-June) (Niizuma 1986) were conducted every year by the Marine Mammal Research Group (MMRG) since 1974. The Kuril Harbour Seal Research Group (KSRG) has conducted population counts since 1982 (Kariya et al. 2006) and, since 1983, in the moulting season as well (Niizuma 1986).

The survey period was normally $1 \mathrm{wk}$ in duration during the May-June pupping season from 1974 to 2010 and during the July-August moulting season from 1983 to 2010, except in 1977. The population counts were conducted primarily during the periods of spring tide; however, in 1975, 1981, 1982, and 1984 and during the moulting period in 1984 and 1987, we conducted the counts at a different tidal stage. At Yururi, Moyururi, Kenbokki, and Daikoku islands, the survey period was $5 \mathrm{~d}$ rather than $1 \mathrm{wk}$ due to logistic constraints. In 1978 (pupping), 2007 (moulting), and 2010 (pupping and moulting), the survey periods were shortened or omitted for some haul-out sites because of personnel shortages and bad weather.

Each year, we conducted a reserve survey in April, usually for 1 to $2 \mathrm{~d}$ at Cape Erimo. We then conducted a pre-pupping survey in May, typically 2 to $3 \mathrm{~d}$. Survey members identified each haul-out site during a survey ( $1 \mathrm{wk})$, and the team, led by an experienced counter, used binoculars $(\times 8)$ and a telescope $(\times 30$ to $\times 40)$ to count the number of landing and swimming seals from $\geq 1$ survey points at each haul-out site. Survey points were at the tops of hillsides or cliffs 60 to $120 \mathrm{~m}$ away from the haul-out site. All the surveys were conducted from the same stations every year.

During the pupping period, we counted the seals and distinguished adults and sub-adults from the pups. During the moulting period, the age structure of the seals (adult, sub-adult, yearling, and pup) was not recorded because our volunteer researchers frequently confused pups with yearlings based on body size and behaviour patterns.

During each count, we also recorded the incidences of seal disturbance by human activity, particularly hunting and other coastal fisheries. We observed 20 
seal hunts until 1984 (Itoo \& Shukunobe 1986). After 1984, no seal hunts were recorded. For intensive surveys undertaken during the period 2003 to 2005, we assessed the population data according to the level of disturbance and the seals' re-haul out time (see Supplement 2 at www.int-res.com/articles/suppl/n024 p061_supp.pdf). We recorded a total of 139 disturbances, the main source of which was coastal fisheries $(30.2 \%)$, and observed that in many cases, the seals re-haul out within $30 \mathrm{~min}$ of the disturbance.

We also recorded all observations of tagged animals. In 2004, we observed 2 tagged seals on Daikoku Island, Akkeshi, during the moulting season from a population of 49 Kuril harbour seals that had been caught and tagged at Harukarimoshiri and Habomai Islands in 2001 (Watanabe 2002).

The present research was conducted in accordance with institutional, national, and international guidelines concerning the use of animals in research and the sampling of endangered species.

\section{Population count data}

We calculated the population growth rate for the entire Hokkaido coastline and each haul-out site during the pupping and moulting periods from 1974 to 2010 and 1982 to 2010, respectively (see 'Statistical analysis'). During the 1970 s and 1980s, Itoo \& Shukunobe (1986) divided the haul-out sites into 4 types and 2 subtypes based on their conservation status: (1a) seals disappeared from the haul-out site due to seal hunting or other human activities in the area (Kenbokki Island and Hattaushi); (1b) very small population being monitored (Yurui Island, Moyururi Island, and Akkeshi A); (2) retains normal function of a haul-out site (Daikoku Island and Cape Erimo); (3) population size greatly increased and needs to be monitored carefully (Hamanaka A); and (4) lacking in information (Hamanaka B). Therefore, we used cluster analysis to evaluate pup, non-pup, and moulting population growth rates by haul-out site type and conducted comparisons between them.

\section{Number of bycatch seals in the autumn salmon set-net fishery}

Bycatch from salmon set-net fishing is one of the most significant issues affecting Kuril harbour seal populations (Association for Protection of Kuril Seals 1983, 1984a, Itoo \& Shukunobe 1986). We carried out an intensive survey at each Fisheries Cooperative Associa- tion site (Nemuro, Hamanaka, Akkeshi, and Cape Erimo) (Fig. 2), then compared the effects of bycatch on seal numbers. Bycatch data for the autumn salmon setnet fishery were collected during intensive surveys from 1981 to 1983 and from 2003 to 2005 in Nemuro, Hamanaka, Akkeshi, and Cape Erimo (e.g. Kobayashi et al. 2007, Kobayashi \& Sakurai 2010). These salmon set-net locations have not changed, and we therefore estimated the increased rates of bycatch by dividing the mean number of bycatch seals recorded during the 2000s by that recorded in the 1980s.

\section{Statistical analysis}

Given that we were missing population count data for some years, we could not directly estimate population growth rates, and consequently, we used a state-space model (Meyer \& Millar 2000, Calder et al. 2003). Below, we describe in detail the process and observation equations.

\section{Process equations}

We assumed that $N_{t+1}$ is distributed as a Poisson distribution, which means $\lambda_{t+1}$, where $N_{t+1}$ is the maximum number of seals during the survey period for Year $t+1$, and $\lambda_{t+1}$ is the true underlying maximum number of seals that can be counted at a haul-out for Year $t+1$.

The annual rate of increase/decrease $(R)$ is calculated as follows:

$$
R_{t}=\frac{\lambda_{t+1}}{\lambda_{t}}
$$

Applying a logarithmic transform gives the following relation:

$$
\log \left(\lambda_{t+1}\right)=\log \left(\lambda_{t}\right)+\log \left(R_{t}\right)=\mu+\sum_{k=0}^{t} \beta_{k}
$$

where $k$ is the dummy variable of Year $t$, and $\mu$ is $\log \left(\lambda_{0}\right)$.

The Poisson distribution ensures that all $N_{t+1}$ values are positive integers. The mean of the Poisson distribution, $\lambda_{t+1}$, depends only on the previous value $\lambda_{t}$ plus the trend $\beta_{t}=\log \left(R_{t}\right)$.

We assumed further that the trend in Year $t$ is correlated with the trend in the previous year, as follows:

$$
\beta_{t} \sim \mathrm{N}\left(\beta_{t-1}, \sigma_{\beta}^{2}\right)
$$

where $\beta_{t}$ is $\log \left(R_{t}\right), \mathrm{N}$ is normal distribution, and $\sigma_{\beta}$ is the standard deviation of the trend. 
A trend at time $t$ is equal to the previous trend plus a small deviation. The parameter $\sigma_{\beta}$ quantifies the variability of use of a haul-out site; large values indicate that a haul-out site may experience large variations in occupancy from one year to the next, while small values denote consistency of use. We assumed that $\beta_{0} \sim N\left(0, \sigma_{\beta}^{2}\right)$.

The average growth rate was calculated as follows:

$$
\bar{R}=\left(\prod_{k=0}^{t} R_{k}\right)^{\frac{1}{t+1}}=\exp \left(\frac{\sum_{k=0,}^{t} \beta_{k}}{t+1}\right)
$$

\section{Observation equations}

Counting the number of landing and swimming seals is easy and takes <10 min. In addition, our survey points and survey protocol have remained virtually unchanged over the past 37 yr. Further, additional population counts were carried out for half a month during the pupping season (May-June) and the moulting season (July-August) in Hamanaka A in 2005. There were no differences between the maximum number of population counts and counting effort, date, and tidal level (GLMM, Poisson distribution, $\mathrm{p}>0.05$, see Supplement 3 at www.int-res.com/ articles/suppl/n024p061_supp.pdf). Accordingly, we believe that our data set is robust in terms of observers and years. However, some random effects, such as weather conditions, tide, and human activities occur, and consequently, we included random effects, $r_{t}$, as follows:

$$
r_{t} \sim \mathrm{N}\left(0, \sigma_{r}^{2}\right)
$$

where $\sigma_{r}$ is the standard deviation of random effects.

Therefore, the maximum number of seals during the survey period for year $t$ is distributed as follows.

$$
\mathrm{N}_{t} \sim \operatorname{Poisson}\left(\lambda_{t}+r_{t}\right)
$$

\section{The effect of seal hunting}

To estimate the influence of hunting on seal population trends, we set dummy variables in the entire Hokkaido (pup, non-pup, and moulting) model. Nakaoka (2004) suggested that seal hunting was active until 1981, occasional during the period 19821985, rare during the period 1986-1989, and absent after 1990. We therefore divided hunting into 3 periods (Hunt 1 to Hunt 3) and used dummy variables; that is to say, hunting until 1981 is Hunt 1, 1982-1985 is Hunt 2, and 1986-1989 is Hunt 3.
Therefore, the process equation was defined as follows:

$$
\log \left(\lambda_{t+1}\right)=\mu+\sum_{k=0}^{t} \beta_{k}+\theta_{1} \text { hunt } 1+\theta_{2} \text { hunt } 2+\theta_{3} \text { hunt } 3
$$

where $\theta_{1}, \theta_{2}$, and $\theta_{3}$ are coefficients for hunting. The observation equation was defined as follows:

$$
\mathrm{N}_{t} \sim \operatorname{Poisson}\left(\lambda_{t}+r_{t}\right)
$$

\section{Prior distribution}

The estimated parameters are as follows: $\mu$, which is equal to $\lambda_{0} ; \sigma_{\beta}$, which is the dispersion of $\beta_{\mathrm{t}}$ and $\sigma_{\mathrm{r}}$ which is the strength of the random effect. Further, the hunting model estimated $\theta_{1}, \theta_{2}$, and $\theta_{3}$. We assumed that these were distributed as uninformative prior distribution.

$$
\begin{aligned}
& \mu \sim \mathrm{N}(0,1000) \\
& \sigma_{\beta} \sim \operatorname{Uni}(0,10000) \\
& \sigma_{r} \sim \operatorname{Uni}(0,10000) \\
& \theta_{1} \sim \mathrm{N}(0,10000) \\
& \theta_{2} \sim \mathrm{N}(0,10000) \\
& \theta_{3} \sim \mathrm{N}(0,10000)
\end{aligned}
$$

We conducted sensitivity analyses of all the prior distributions. The sensitivity analysis was performed by changing the limits of the uniform distribution or the variance of the normal distribution. We increased the limits of the uniform distribution to double the original and increased the variance of the normal distribution 10-fold. These operations were conducted without changing other values. According to the sensitivity analyses, the effects of uninformative prior distribution were very small.

\section{Implementation}

This simple state-space model allows direct estimation of trends from the data, even if $N_{t}$ is 0 . It also efficiently uses all of the information in the data set to estimate the variability of the trends.

We used R, v. 2.15.1 (R Development Core Team 2012), and BUGS software (e.g. Spiegelhalte et al. 2003). We ran 100000 iterations, discarded the first 80000 as burn-in, and applied a thinning ratio of 10 . We ran multiple chains as 3. Assessment of Convergence diagnostics were assessed using the BrooksGelman-Rubin statistic ( $\widehat{R}$ ) (Gelman \& Rubin 1992, Brooks \& Roberts 1998), and we confirmed that all our models had $\widehat{R} \leq 1.1$. 


\section{RESULTS}

\section{Population status and population parameters}

Population count data are provided in Supplements 4 and 5 (www.int-res.com/articles/suppl/n024p061_ supp.pdf). In total, 11 haul-out sites were identified along the Hokkaido coast during the course of this study. While not all of these sites have been continually occupied, the number of pupping sites increased from 8 in 1974 to 9 in 2010. In 2010, seals were observed at 9 haul-out sites during the pupping and/or moulting period: Yurui Island, Moyururi Island, Hamanaka A, Hamanaka B, Akkeshi A, Akkeshi B, Akkeshi C, Daikoku Island, and Cape Erimo.

The number of Kuril harbour seals has quadrupled in the past 37 years (Table 1). The largest number was 1089 in 2008 in the moulting period. The Association for Protection of Kuril Seals (1984a,b) compared maximum count data with close haul-out sightings for the same date and time in 1983. The overall proportions were 94.9 and $97.8 \%$ (pup: 37/39, non-pup: $226 / 231$ ) in the pupping period and $88.5 \%(295 / 344)$ in the moulting period. This gave values of approximately 81.0 and $77.3 \%$ (pup: 17/21, non-pup: 133/172) in the pupping period and $89.4 \%(474 / 530)$ in the moulting period in 2009 (6 haul-out sites, except Cape Erimo).

Region wide (omitting Akkeshi B, Akkeshi C, and Kenbokki Island), annual growth rates were 1.0321 (pups) and 1.0410 (non-pups) during the pupping period and 1.0295 during the moulting period. The growth rate could not be estimated for Hattaushi \& Kenbokki Island during the pupping season because there are many records with no data or with counts of 0 .

We constructed a random effects model and a hunting model, which took into account population trends and hunting, respectively (Figs. 3 \& 4). The random effects model showed that the seal's population trend is increasing consistently. The hunting model indicated that seal hunting had suppressed the population growth until the late 1980s. In the hunting model, $\theta_{1}$, $\theta_{2}$, and $\theta_{3}$ of pups are $-0.77,-0.62$, and -0.43 , respectively. For non-pups, the effects of hunting are -0.40 , -0.13 , and -0.03 , and for moulting, $\theta_{2}$ and $\theta_{3}$ are

Table 1. Average Kuril harbour seal population growth rates using a statespace model of the pupping period for 1974 to 2010 and the moulting period for 1983 to 2010 for all of Hokkaido and for each other individual haul-out site (see Fig. 2 for details). In each case, the top row shows pups in the pupping period, the middle row shows non-pups in the pupping period, and the lower row shows all seals in the moulting period. $n$ : the number of years that we can investigate; (-) no data available

\begin{tabular}{|c|c|c|c|c|c|c|c|}
\hline \multirow{2}{*}{ Area } & \multirow{2}{*}{ Haul-out site } & \multirow[t]{2}{*}{$\mathrm{n}$} & \multirow{2}{*}{ Mean } & \multirow[t]{2}{*}{ Median } & \multirow[t]{2}{*}{ SE } & \multicolumn{2}{|c|}{$95 \%$ CI } \\
\hline & & & & & & Lower & Upper \\
\hline \multirow[t]{3}{*}{ Hokkaido } & & 36 & 10.355 & 10.354 & 0.0062 & 10.233 & 10.475 \\
\hline & & & 10.434 & 10.435 & 0.0039 & 10.357 & 10.509 \\
\hline & & 27 & 10.323 & 10.323 & 0.0042 & 10.238 & 10.404 \\
\hline \multirow[t]{3}{*}{ Hokkaido $^{\mathrm{a}}$} & & 36 & 10.321 & 10.320 & 0.0065 & 10.198 & 10.455 \\
\hline & & & 10.410 & 10.410 & 0.0040 & 10.328 & 10.486 \\
\hline & & 27 & 10.295 & 10.296 & 0.0042 & 10.211 & 10.377 \\
\hline \multirow[t]{6}{*}{ Nemuro } & Yururi & 36 & 0.9979 & 0.9985 & 0.0090 & 0.9781 & 10.147 \\
\hline & & & 0.9850 & 0.9851 & 0.0116 & 0.9630 & 10.082 \\
\hline & & 27 & 0.9906 & 0.9908 & 0.0227 & 0.9446 & 10.366 \\
\hline & Moyururi & 36 & 10.079 & 10.077 & 0.0165 & 0.9757 & 10.405 \\
\hline & & & 10.166 & 10.162 & 0.0134 & 0.9909 & 10.431 \\
\hline & & 27 & 11.062 & 11.055 & 0.0242 & 10.579 & 11.538 \\
\hline \multirow[t]{12}{*}{ Hamanaka } & Hamanaka A & 36 & 0.9868 & 0.9868 & 0.0098 & 0.9666 & 10.050 \\
\hline & & & 10.253 & 10.252 & 0.0082 & 10.097 & 10.420 \\
\hline & & 27 & 10.090 & 10.093 & 0.0059 & 0.9972 & 10.204 \\
\hline & Hamanaka B & 12 & 0.9222 & 0.9211 & 0.0640 & 0.7978 & 10.500 \\
\hline & & 12 & 0.9788 & 0.9795 & 0.0234 & 0.933 & 10.252 \\
\hline & & $13^{\mathrm{b}}$ & 10.056 & 10.025 & 0.0555 & 0.8907 & 11.228 \\
\hline & Hattaushi & - & - & - & - & - & - \\
\hline & & 36 & 0.7580 & 0.7731 & 0.0887 & 0.5742 & 0.8964 \\
\hline & & - & - & - & - & - & - \\
\hline & Kenbokki & - & - & - & - & - & - \\
\hline & & - & - & - & - & - & - \\
\hline & & - & - & - & - & - & - \\
\hline \multirow[t]{12}{*}{ Akkeshi } & Akkeshi A & 36 & 0.9908 & 0.9929 & 0.0216 & 0.9463 & 10.313 \\
\hline & & & 0.9786 & 0.9800 & 0.0140 & 0.9503 & 10.029 \\
\hline & & 27 & 10.838 & 10.834 & 0.0148 & 10.537 & 11.120 \\
\hline & Akkeshi B & 13 & 0.9712 & 0.9713 & 0.0214 & 0.9296 & 10.129 \\
\hline & & & 10.484 & 10.483 & 0.0145 & 10.210 & 10.773 \\
\hline & & 12 & 0.4946 & 0.5180 & 0.2463 & - & 0.8644 \\
\hline & Akkeshi C & 12 & 0.5918 & 0.6025 & 0.6363 & - & 10.017 \\
\hline & & & - & - & - & - & - \\
\hline & & 13 & 10.404 & 10.393 & 0.0351 & 0.9768 & 11.111 \\
\hline & Daikoku & 36 & 10.219 & 10.219 & 0.0009 & 10.042 & 10.396 \\
\hline & & & 10.394 & 10.393 & 0.0035 & 10.328 & 10.465 \\
\hline & & 27 & 10.244 & 10.244 & 0.0045 & 10.154 & 10.333 \\
\hline \multirow[t]{3}{*}{ Cape Erimo } & & 36 & 10.579 & 10.580 & 0.0152 & 10.281 & 10.869 \\
\hline & & & 10.546 & 10.545 & 0.0063 & 10.423 & 10.670 \\
\hline & & 27 & 10.302 & 10.303 & 0.0067 & 10.170 & 10.440 \\
\hline
\end{tabular}



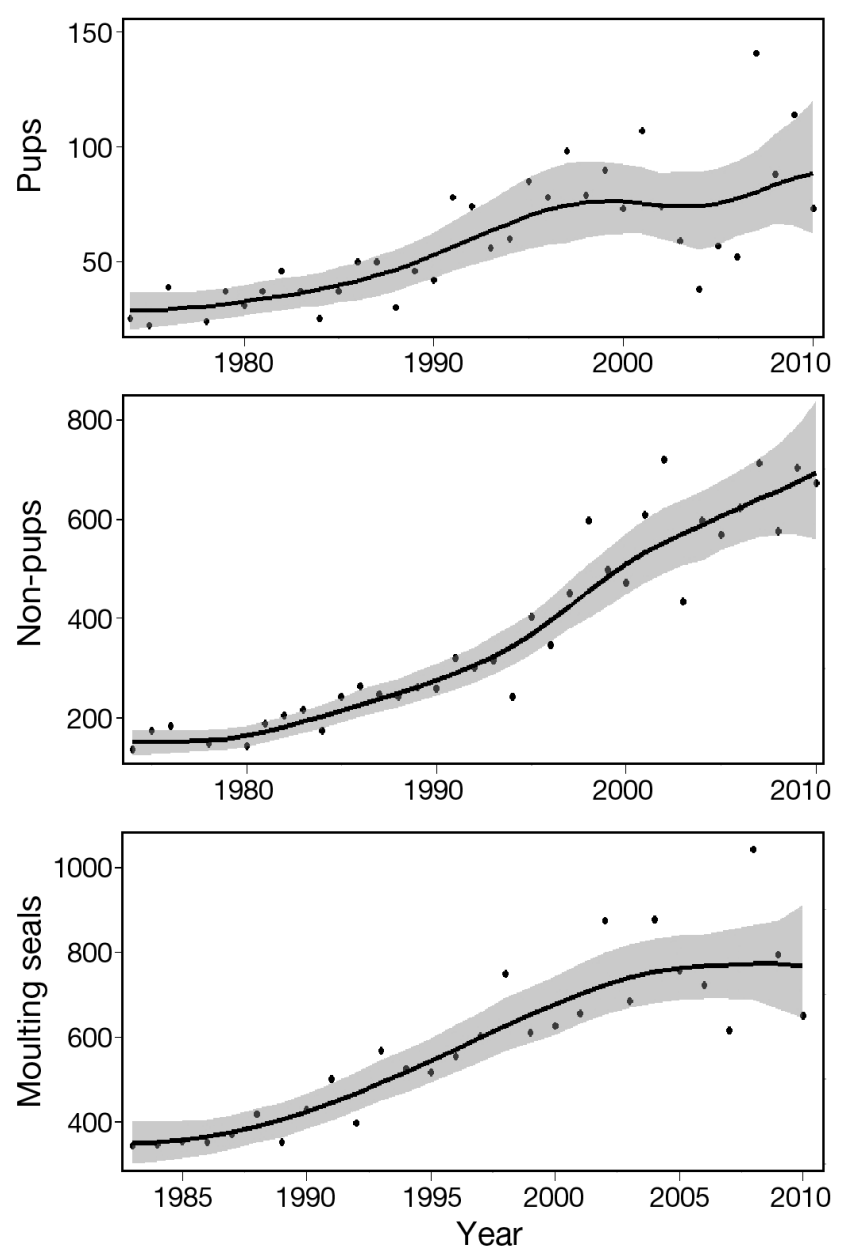

Fig. 3. Number of Kuril harbour seals in southeastern Hokkaido, Japan (dots), and smoothed estimates (with 95\% credibility intervals), based on a Bayesian state-space model, during the pupping periods of 1974 to 2010 and the moulting periods of 1983 to 2010

-0.13 and -0.12 , respectively. Notably, the elasticity, calculated as $100 \times\left[\exp \left(\theta_{1}\right)-1\right]$, for pup $\theta_{1}$ is $-53.8 \%$, and that for non-pup $\theta_{1}$ is $-33 \%$. These are relatively large values.

Table 2 shows the present status of each Kuril harbour seal haul-out site along with changes in the status of haul-out site types from the 1980s to the 2000s.

Type 1a sites include Kenbokki Island and Hattaushi haul-out sites, where seals had disappeared due to seal hunting or other human activities in the area in the $1980 \mathrm{~s}$, and these remained Type 1a sites in the 2000s. In contrast, the 1980s Type 1b (very small population being monitored) sites (Yururi Island, Moyururi Island, and Akkeshi A) had improved to Type $2 \mathrm{a}$ or $2 \mathrm{~b}$.

Type 2 sites, which retain the normal function of haul-out sites, have been divided into 3 new sub-
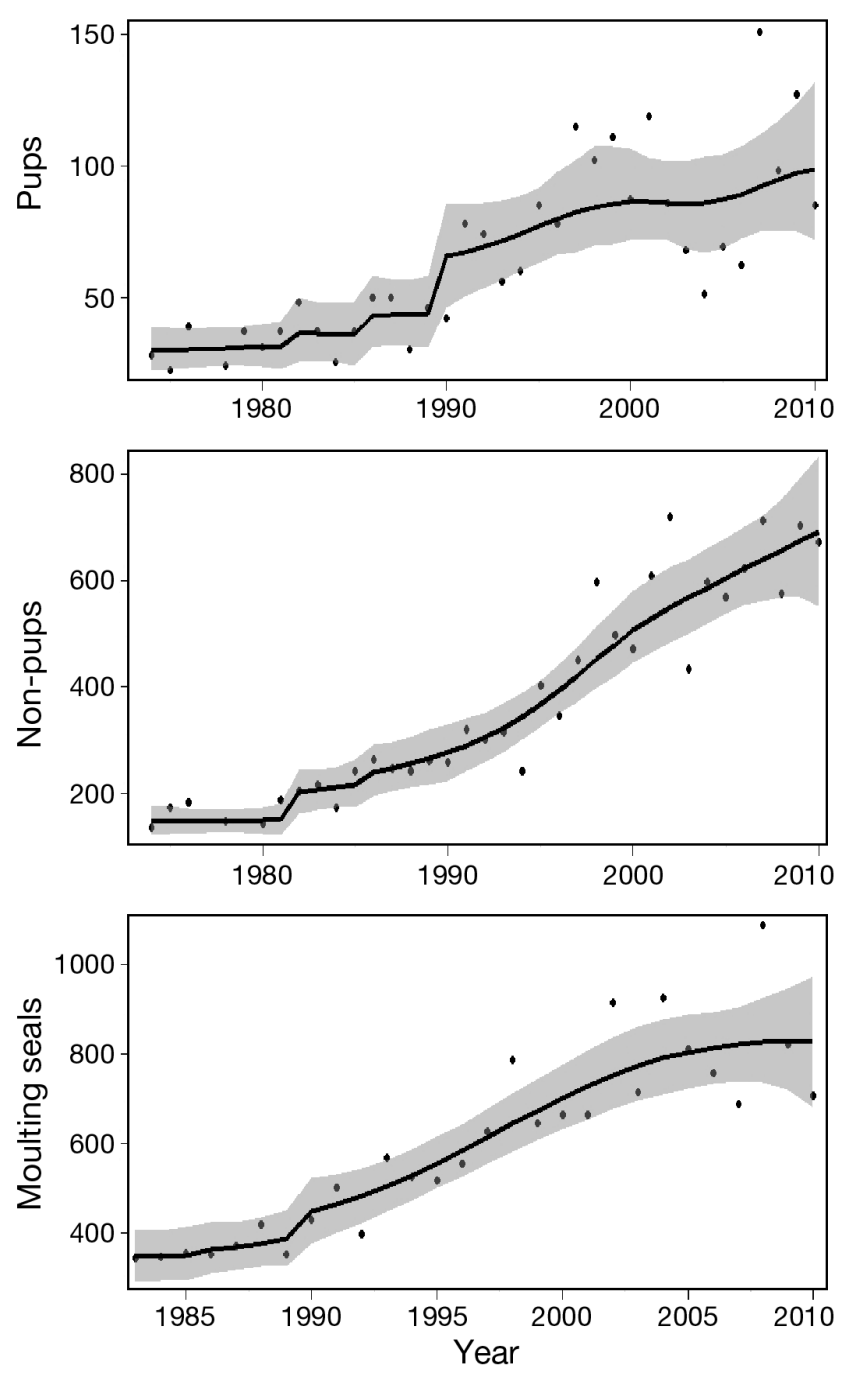

Fig. 4. The hunting model using dummy variables with hunts 1-4 (1: active hunting until 1981; 2: occasional hunting [1982-1985]; 3: rare hunting [1986-1989]; 4: hunting absent [after 1990]) (Nakaoka 2004) for the entire Hokkaido area. The number of Kuril harbour seals in southeastern Hokkaido, Japan (dots), and smoothed estimates (with 95\% credibility intervals) using a Bayesian state-space model are shown

classes based on size. Type 2a includes those whose population size has been nearly stable, with small pupping and large moulting populations (currently Moyururi Island and Akkeshi A). Type 2b sites are nearly stable but have had some decreases in certain seasons or for certain durations (currently Yururi Island, Hamanaka A, and Hamanaka B). Type 2c sites have had population increases at a constant rate (Daikoku Island and Cape Erimo); these sites are important pupping and moulting sites, and $\geq 70 \%$ of the population of southeastern Hokkaido inhabits these sites. 
Table 2. Changes in status of Kuril harbour seal haul-out sites from the 1980s to the 2000s. Arrows indicate changes in site status from one type to another (for details of the different types see 'Results'). Data for the 1980s are from Itoo \& Shukunobe (1986)

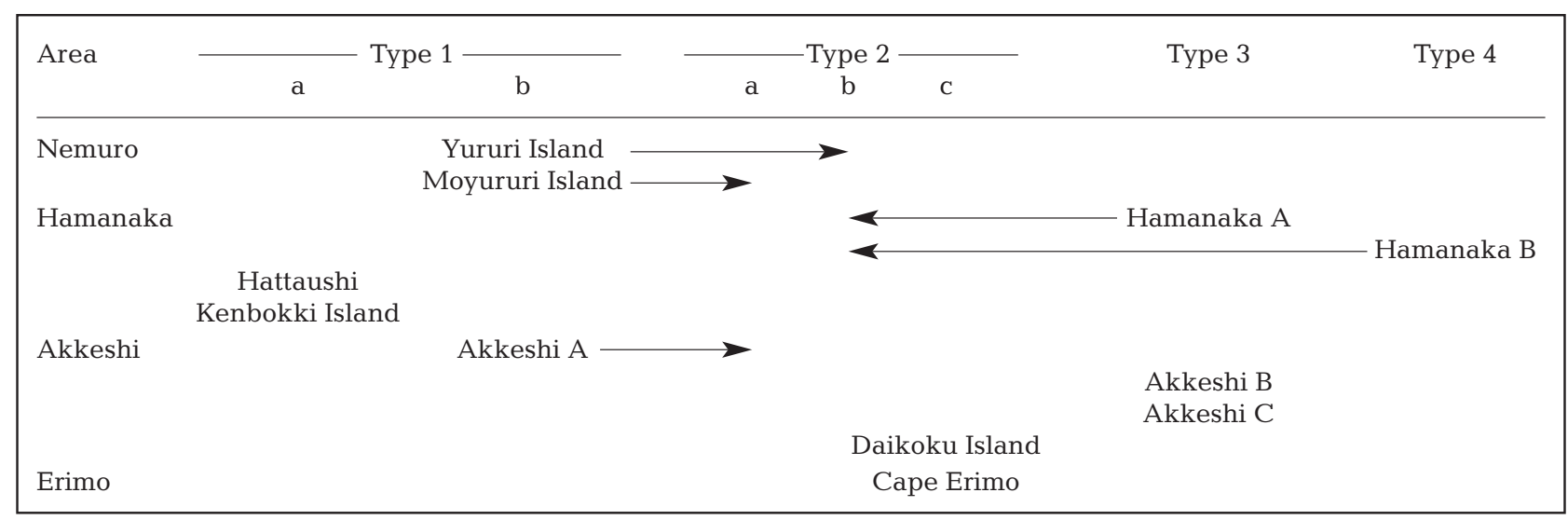

Type 3 sites include those in which the population has increased during one of the seasons (Akkeshi B and Akkeshi C). For example, at Akkeshi B, many seals were observed during the pupping period, but only a few were seen during the moulting period.

The previous Type 4 site (lacking in information), Hamanaka B, has changed to Type $2 \mathrm{~b}$.

\section{The influence of bycatch from the autumn salmon set-net fishery}

The number of seals trapped as bycatch during the autumn salmon set-net fishery and the increase rates for each area in Nemuro, Hamanaka, Akkeshi, and Cape Erimo are shown in Fig. 5. The mean $( \pm \mathrm{SD})$ numbers of bycaught seals from 2003 to 2005 were $128.0 \pm 4.4,11.7 \pm 2.9,13.3 \pm 3.1$, and $15.7 \pm 6.1$ in Nemuro, Hamanaka, Akkeshi, and Cape Erimo, respectively (Fujii \& Nakagawa 2006, Saito 2006, Kobayashi et al. 2007, Kobayashi \& Sakurai 2010, Kobayashi 2011). The bycatch increased from the 1980s to the 2000s in each area 1.3-, 1.6-, 4.4-, and 2.2-fold, respectively. The autumn salmon set-net fishery negatively affected the Kuril harbour seal population. In the Nemuro area in particular, the number of bycatch seals was markedly higher than the number of seals counted during the moulting period.

\section{DISCUSSION}

\section{Population status of Kuril harbour seals}

We found that Kuril harbour seal populations probably did not recover until the late 1980s and that since the 1990s, the number of seals in southeastern
Hokkaido has consistently increased. However, if not all the seals are on the beach at one time, then even the maximum counts are an underestimate of the population abundance. Nevertheless, we compared count data with maximum counts for the same date for all haul-out sites in 1983 and 2009 and obtained values of $\sim 80 \%$ or more. Therefore, we believe that our data estimating the long-term increase or decrease in Kuril harbour seal population trends in southeastern Hokkaido are valid.

The population growth rate of harbour seals in Alaska is estimated at -1.3 to $7.4 \%$ (Small et al. 2003), 6\% in Maine, USA (Gilbert et al. 2005), and $\sim 11 \%$ in Europe (Härkönen et al. 2002). The growth rates we observe are low relative to the mean possible $(4 \%)$ and are probably the consequence of anthropogenic activities that reduce population growth, such as hunting and bycatch in local fisheries (Table 3). Bycatch remains a serious problem for Kuril Harbour seals, and $>50$ seals are caught each year in the Cape Erimo area (Fujii \& Nakagawa 2006). Reducing the number of seals caught as bycatch will no doubt have a positive effect on population growth rates. However, because Kuril harbour seals migrate between eastern Hokkaido and the Habomai Islands (based on tag recoveries), any bycatch mitigation needs to occur at a regional rather than a local level.

\section{Conservation and management policies}

Conserving and managing mobile species such as seals is difficult because management policies need to be regionally based and incorporate local, national, and international conservation bodies and occur across many socio-economic activities, e.g. recreational and industrial fisheries. Conserving the unique 

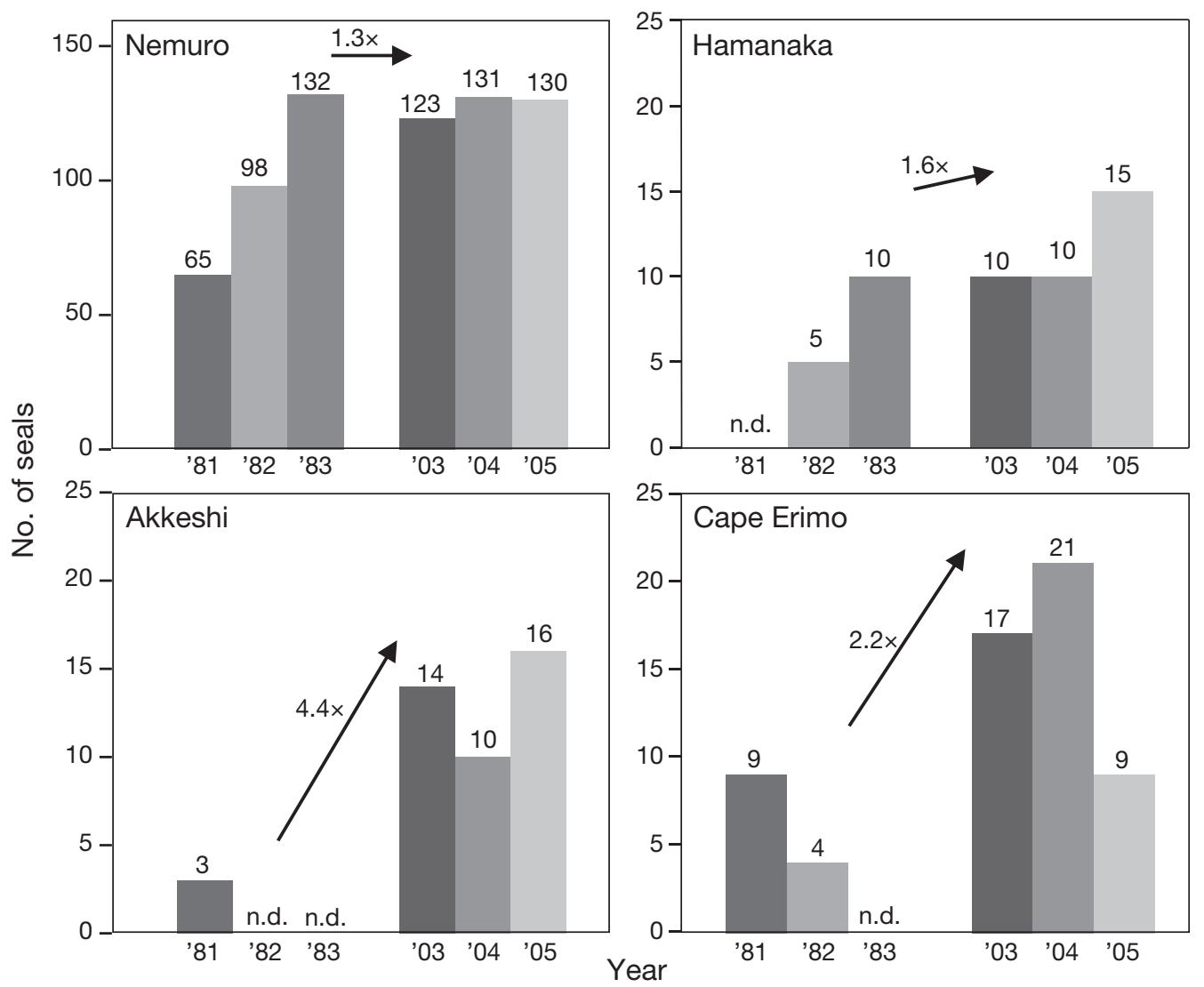

Fig. 5. Number of Kuril harbour seals trapped as bycatch during the autumn salmon set-net fishery in Nemuro, Hamanaka, Akkeshi, and Cape Erimo (Itoo \& Wada 1983, Tanahashi \& Itoo 1986, Wada et al. 1986, 1991 for 1982-1983; Fujii \& Nakagawa 2006, Saito 2006, Kobayashi et al. 2007, Kobayashi 2011 for 2003-2005). Arrows show the increase in the rate of bycatch estimated by dividing the mean number of bycaught seals during the 2000 s by that for the 1980s. n.d.: not determined

Table 3. Overview of the Kuril harbour seal population, population count surveys, haul-out sites, laws, and hunting information from the 1940s to the 2000s in southeastern Hokkaido, Japan. Sources are given in parentheses and are as follows: 1: Inukai (1942a,b); 2: Itoo \& Shukunobe (1986); 3: Nakaoka (2004); 4: Suzuki (1986); 5: Kobayashi \& Sakurai (2010); 6: Chishima (1997); and 7: present article

\begin{tabular}{|c|c|c|c|c|c|}
\hline & $1940 \mathrm{~s}$ & $1970 \mathrm{~s}$ & $1980 \mathrm{~s}$ & $1990 \mathrm{~s}$ & $2000 \mathrm{~s}$ \\
\hline Population & $1500-4800(1,2)$ & $\begin{array}{l}\text { Pupping: } 150 \\
(2,6,7)\end{array}$ & $\begin{array}{l}\text { Pupping: } 200-250 \\
\text { Moulting: } 350 \\
(2,6,7)\end{array}$ & $\begin{array}{l}\text { Pupping: } 300-500 \\
\text { Moulting: } 350-550 \\
(6,7)\end{array}$ & $\begin{array}{l}\text { Pupping: } 600-800 \\
\text { Moulting: } 1000 \\
\text { (7) }\end{array}$ \\
\hline Population counts & & $\begin{array}{l}\text { First survey, } \\
\text { December } 1973(2) \\
\text { Pupping survey } \\
\text { start, } 1974(2,6,7)\end{array}$ & $\begin{array}{l}\text { Moulting survey } \\
\text { start,1983 }(2,6,7)\end{array}$ & \multirow[t]{2}{*}{$\begin{array}{l}\text { Hamanaka B } \\
\text { unsurveyed from } \\
\text { 1988-1997 (7); } \\
\text { Akkeshi B, C } \\
\text { since } 1997(7)\end{array}$} & \\
\hline $\begin{array}{l}\text { Disappearances } \\
\text { at haul-out sites }\end{array}$ & & $\begin{array}{l}\text { Kenbokki Island } \\
(2,7)\end{array}$ & Hattaushi $(2,7)$ & & \\
\hline Applicable laws & & & & $\begin{array}{l}\text { 1992, Endangered } \\
\text { Species }^{\mathrm{a}}\end{array}$ & $\begin{array}{l}\text { 2003, The Revised Birds } \\
\text { and Mammals Protection } \\
\text { LAW, Endangered Species }\end{array}$ \\
\hline $\begin{array}{l}\text { Hunting } \\
\text { information }\end{array}$ & $\begin{array}{l}\text { Several thousand } \\
\text { seals per year (1) }\end{array}$ & Activity $(2,3,4)$ & $\begin{array}{l}\text { Occasional or } \\
\text { rare (3) }\end{array}$ & None $(6,7)$ & None $(3,5,7)$ \\
\hline $\begin{array}{l}\text { Link between local } \\
\text { people and seals }\end{array}$ & $\begin{array}{l}\text { Strong; used for } \\
\text { food and other } \\
\text { items (1) }\end{array}$ & $\begin{array}{l}\text { Strong; used for food } \\
\text { and other items (1) }\end{array}$ & $\begin{array}{l}\text { Strong; used for food } \\
\text { and other items (3) }\end{array}$ & \multicolumn{2}{|c|}{$\begin{array}{l}\text { Weak; not used for subsistence, hope for } \\
\text { sightseeing (3) }\end{array}$} \\
\hline
\end{tabular}


Kuril seal in Japan is not straightforward despite the seal's nationally endangered status, given that many of the constraints mentioned above are pertinent to this case. While seal numbers have increased during the past $37 \mathrm{yr}$ in Japan, the rate of recovery has been slower than might be expected for this species, and perhaps more worryingly, the increases have occurred locally without the re-colonization of previously depleted sites. These high densities of seals at only a few of many potential haul-out sites is of concern, given that the probability of local extinctions are likely if, for example, an infectious disease were to enter one of these sub-populations. Consequently, conservation efforts across the entire range of the Kuril seals needs to be a priority, and programs such as the Sea of Okhotsk cooperative conservation program can play an important role in the ongoing viability of these populations (Sakurai et al. 2013).

Acknowledgements. The authors thank volunteer investigators ( $>1500$ people) belonging to the Marine Mammal Research Group, Obihiro University of Agriculture and Veterinary Medicine Kuril Harbour Seal Research Group, Pinniped Research Group, Sea Lion Working Group, Brown Bear Research Group of Hokkaido University, Nature Conservation Group of Obihiro Zoo, Kushiro Zoo, Nature Conservation Society of Obihiro University, Natural Inquiry Association of Obihiro University, and many students of Agriculture and Veterinary Medicine, Obihiro University, Hokkaido University, Nihon University, Nippon Veterinary and Life Science University, Kyoto University, Tokyo University of Marine Science and Technology, and Rakuno Gakuen University. We also thank the local people and fishermen for supporting our field work and the Erimo Seal Club (A. Ishikawa, K. Yanagida, S. Ishikawa et al.), Nemuro City and Akkeshi, Hamanaka and Erimo Town Board of Education, Hokkaido Akkeshi Forestry Center, Akkeshi Memorial Hall for Marine, Akkeshi Waterfowl Observation Center, Akkeshi Marine Station, Aquatic Research Station Field Science Center for Northern Biosphere of Hokkaido University, Kiritappu Wetland Center, Erimo Tourism Association, and Erimo Wind Pavilion. We thank T. Kasajima (deceased) and F. Kasajima, the landowners of Daikoku Island, K. Souma (deceased) and T. Souma, the landowners of the Hamanaka A haul-out site, M. Usui, landowner of the Hattaushi haulout site, and S. Yamazaki, K. Tangoya, S. Tatsunami, K. Honda (deceased), and A. Honda. We acknowledge Y. Watanuki, M. Sasaki, H. Uno, S. Yabuta, Y. W. Nakayama, T. Matsuishi, K. Simatani, and Hu. Y. Satou for their helpful comments on this study. We thank the reviewers for their helpful comments and suggestions. The present study was funded by World Wide Fund for Nature of Japan committee (WWF-J) (1974-1976, 1981-1982, 1984), Nippon Insurance Foundation (1982-1983), Toyota Foundation (1985-1986), Nature Conservation Society of Japan (1990), Kiritappu Wetland Science Research Grant (2005-2006), Maeda Ippoen Foundation (1984, 2006, 2012), Nippon Life Insurance Foundation (2010), Earth Watch Japan (1997), Ministry of the Environment of Japan (J-IBIS: 1998-2000, ERTDF: 4-1301), and the Institute of Statistical Mathematics, Japan (2011-ISM · CRP-5002, 25-ISM · CR-2008).

\section{LITERATURE CITED}

Alaska Sea Grant (1993) Is it food? Addressing marine mammal and sea bird declines, workshop summary. In: Alaska Sea Grant College Program Report 93-01. University of Alaska, Fairbanks, AK

Anderson JP, Piatt JF (1999) Community reorganization in the Gulf of Alaska following ocean climate regime shift. Mar Ecol Prog Ser 189:117-123

Association for Protection of Kuril Seals (1983) Report of the Census for the Kuril Seal along the Pacific Coast of Eastern Hokkaido in October, 1982. In: Nakaoka T, Hayama S, Osada H (eds) Mamm Sci (Honyurui Kagaku) 46: 21-28 (in Japanese)

Association for Protection of Kuril Seals (1984a) Report of the Census for the Kuril Seals in breeding season along the Pacific Coast of eastern Hokkaido in June, 1983. In: Uno H (ed) Mamm Sci (Honyurui Kagaku) 49:41-48 (in Japanese)

Association for Protection of Kuril Seals (1984b) Report of the Census for the Kuril Seal along the Pacific Coast of eastern Hokkaido in August (molting season), 1983. In: Shibata R, Osada H (eds) Mamm Sci (Honyurui Kagaku) 48:41-52 (in Japanese)

Bigg MA (1969) The harbour seal in British Columbia. Bull Fish Res Board Can 172, Ottawa

Bigg MA (1981) Harbour seal: Phoca vitulina Linnaeus, 1758 and Phoca largha Pallas, 1811. In: Rindgway SH, Harrison, RJ (eds) Handbook of marine mammals, Vol 2: Seals. Academic Press, New York, NY, p 1-27

Brooks SP, Roberts GO (1998) Convergence assessment techniques for Markov chain Monte Carlo. Stat Comput 8:319-335

Brown RF, Wright BE, Riemer SD, Jeffrey L (2005) Trends in abundance and current status of harbor seals in Oregon: 1977-2003. Mar Mamm Sci 21:657-670

Burg TM, Andrew WT, Smith MJ (1999) Mitochondrial and microsatellite DNA analyses of harbour seal population structure in the northeast Pacific Ocean. Can J Zool 77: 930-943

Calder C, Lavine M, Peter M, Clark JS (2003) Incorporating multiple sources of stochasticity into dynamic population models. Ecology 84:1395-1402

Chishima J (1997) Report of survey of number of Kuril harbor seal (census) individuals in 1996. Wildl Forum 3: 113-118 (in Japanese)

Chyupakhina TI, Panteleeva OI (1991) A report on the distribution and number of marine mammals in the Kuril Island. Sakhalinrybvod, Yuzhno-Sakhalinsk (in Russian)

Far East Pinniped Research Group (ed) (1993) Report of marine mammal survey southern part islands 1992 year. Polar Eastern Pinniped Research Group, Japan (in Japanese)

Fujii K, Nakagawa E (2006) Fishery damage and by-catch of seals. 1) Cape Erimo area. In: NPO Marine Wildlife Center of Japan (ed) Report on conservation and management of seals. Hokkaido Government, Hokkaido, p 133-140 (in Japanese)

Fujii K, Sato H, Kakumoto C, Kobayashi M and others (2006) Seroepidemiological survey of morbillivirus infection in Kuril harbor seals (Phoca vitulina stejnegeri) of Hokkaido. Jpn J Vet Res 54:109-117

Fujii K, Kakumoto C, Kobayashi M, Saito S and others (2007a) Serological evidence of influenza A virus infection in Kuril harbor seals (Phoca vitulina stejnegeri) of 
Hokkaido, Japan. J Vet Med Sci 69:259-263

Fujii K, Kakumoto C, Kobayashi M, Saito S and others (2007b) Seroepidemiology of Toxoplasma gondii and Neospora caninum in seals around Hokkaido, Japan. J Vet Med Sci 69:393-398

Gelman A, Rubin D (1992) Inference from iterative simulation using multiple sequences. Stat Sci 7:457-511

Gilbert JR, Waring GT, Wynne KT, Guldager N (2005) Changes in abundance of harbor seals in Maine, 19812001. Mar Mamm Sci 21:519-535

Härkönen T, Harding KC, Heide-Jørgensen MP (2002) Rates of increase in age-structured populations: a lesson from the Europian harbour seals. Can J Zool 80:1498-1510

Hayama S (1988) Kuril seal-present status in Japan. Ambio $17: 75-78$

Inukai T (1942a) True seals in Northern Ocean (1). Plants Anim 10:927-932 (in Japanese)

Inukai T (1942b) True seals in Northern Ocean (2). Plants Anim 10:1025-1030 (in Japanese)

Itoo T, Shukunobe T (1986) Number and present status of the Kuril seal. In: Wada K, Itoo T, Niizuma A, Hayama S, Suzuki M (eds) Ecology and protection of Kuril seal. Tokai University Press, Tokyo, p 18-58 (in Japanese with English abstract)

Itoo T, Wada K (1983) An inquiry report into damage of the inshore fisheries caused by the Kuril seal on the coastal waters of Eastern Hokkaido, Japan. Mamm Sci (Honyurui Kagaku) 45:93-107

IUCN (International Union for Conservation of Nature) (2012) IUCN Red List of Threatened Species, Vers 2012.2. IUCN SSC Pinniped Specialist Group (2008) Phoca vitulina. www.iucnredlist.org (accessed 23 April 2013)

Japanese Environment Agency (1992) Red List of Threatened Animals. www.biodic.go.jp/rdb/rdb_f.html (accessed 20 September 2010)

Japanese Fisheries Agency (2000) Red List of Threatened Aquatic Animals. Japan Fisheries Resource Conservation Association, Tokyo (in Japanese)

Japanese Ministry of the Environment Agency (2003) Law concerning making of protection and hunting of birds and beasts proper. www.env.go.jp/press/file_view.php?serial =20550\&hou_id=15619 (accessed 20 September 2010)

Japanese Ministry of the Environment Agency (2012) Red List of Threatened Animals. www.biodic.go.jp/rdb/ rdb_f.html (accessed 20 September 2012)

Jeffries S, Huber H, Calambokidis J, Laake J (2003) Trends and status of harbor seals in Washington state: 19781999. J Wildl Manag 67:207-218

Jefferson TA, Leatherwood JS, Webber MA (1993) FAO special identification guide, marine mammals of the world. FAO, Rome

Kariya T, Kobayashi Y, Fujii K, Yamada K and others (2006) Kuril harbor seal (Phoca vuitulina stejnegeri) conservation and ecology in Hokkaido, Japan. Wildl Forum 11: 25-38

Kobayashi Y (2011) Population trend and management of Kuril harbor seal around eastern Hokkaido, Japan. PhD dissertation, Graduate School of Fisheries Science, Hokkaido University, Hakodate (in Japanese)

Kobayashi Y, Sakurai Y (2010) Questionnaire survey and stranding records of Kuril harbor seal Phoca vitulina stejnegeri and other marine mammals in Hamanaka, eastern Hokkaido, Japan. Nemuro Museum Hist Nat 22: 29-36 (in Japanese with English abstract)
Kobayashi M, Ishinazaka T, Kakumoto C, Watanabe $\mathrm{H}$, Kobayashi Y, Shimizu A (2007) Survey of the number of seals incidentally caught by salmon trap nets along the coastal waters of the Nossapu Cape in Nemuro Peninsula from 2002 to 2003 compared with the survey from 1982 to 1983. Mamm Sci (Honyurui Kagaku) 47:207-214

Meyer R, Millar RB (2000) Bayesian state-space modeling of age structured data: fitting a model is just the beginning. Can J Fish Aquat Sci 57:43-50

Naito Y, Nishiwaki M (1972) The growth of two species of the harbor seals in the adjacent waters of Hokkaido. Whale Res Inst 24:127-144

Nakagawa E, Kobayashi M, Suzuki M, Tsubota T (2010) Genetic variation in the harbor seal (Phoca vitulina) and spotted seal (Phoca largha) around Hokkaido, Japan, based on mitochondrial cytochrome b sequences. Zool Sci 27:263-268

Nakaoka T (2004) Relations between Kuril harbor seal and people at Cape Erimo. In: Kobayashi M, Ishono T, Hattori $\mathrm{K}$ (eds) Management of marine mammals along the coast of Hokkaido, Japan. Marine Wildlife Center of Japan, Sapporo, p 97-105 (in Japanese)

Niizuma A (1986) Socio-ecology and reproductive strategy of the Kuril seal. In: Wada K, Itoo T, Niizuma A, Hayama S, Suzuki M (eds) Ecology and protection of Kuril seal. Tokai University Press, Tokyo, p 59-102 (in Japanese with English abstract)

Niizuma A, Hayama S (1986) A review of the taxonomy of the Kuril seal and other members of the genus Phoca (sensu stricto). In: Wada K, Itoo T, Niizuma A, Hayama S, Suzuki M (eds) Ecology and protection of Kuril seal. Tokai University Press, Tokyo, p 1-18 (in Japanese with English abstract)

Niizuma A, Naito Y, Itoo T, Wada $K$, Abe H, Ohtaishi N, Nishiwaki M (1980) Number and present status of the Kuril seal, Phoca kurilensis INUKAI, 1942 along the Pacific coast of the Eastern Hokkaido. J Mamm Soc 8: 97-104 (in Japanese with English abstract)

R Development Core Team (2012) R: a language and environment for statistical computing. R Foundation for Statistical Computing, Vienna, Austria. www.r-project.org (accessed 4 September 2012)

Saito S (2006) Fishery damage and by-catch of seals. 2) Akkeshi area. In: NPO Marine Wildlife Center of Japan (ed) Report on conservation and management of seals. Hokkaido Government, Hokkaido, p 141-147 (in Japanese)

Sakurai Y, Ohshima KY, Ohtaishi N (2013) Ecosystem and its conservation in the Sea of Okhotsk. Hokkaido University press, Sapporo (in Japanese with English abstract)

Shaughnessy PD, Fay FH (1977) A review of the taxonomy and nomenclature of North Pacific harbor seals. J Zool 182:385-419

Small RJ, Pendleton GW, Pitcher KW (2003) Trends in abundance of Alaska harbor seals, 1983-2001. Mar Mamm Sci 19:344-362

Spiegelhalte D, Thomas A, Best N, Lunn D (2003) WinBUGS user manual, Vers 1.4. MRC Biostatistics Unit, Cambridge. www.mrc-bsu.cam.ac.uk/bugs (accessed 4 September 2012)

Suzuki M (1986) Process and some problems on the protection of Kuril seals during the past 13 years. In: Wada K, Itoo T, Niizuma A, Hayama S, Suzuki M (eds) Ecology and protection of Kuril seal. Tokai University Press, Tokyo, p 342-351 (in Japanese with English abstract) 
Tanahashi K, Itoo T (1986) Estimation of damage by Kuril seals to some trap net fisheries at Cape Erimo. In: Wada K, Itoo T, Niizuma A, Hayama S, Suzuki M (eds) Ecology and protection of Kuril seal. Tokai University Press, Tokyo, p 257-273 (in Japanese with English abstract)

Wada K, Hayama S, Nakaoka T, Uno H (1986) On the interactions between Kuril seals and salmon trap net fisheries along the coastal waters of south-eastern Hokkaido. In: Wada K, Itoo T, Niizuma A, Hayama S, Suzuki M (eds) Ecology and protection of Kuril seal. Tokai University Press, Tokyo, p 223-244 (in Japanese with English abstract)

Wada K, Hayama S, Nakaoka T, Uno H (1991) Interactions between Kuril seals and salmon trap net fishery in the

Editorial responsibility: Clive McMahon,

Darwin, Northern Territory, Australia coastal waters of southeastern Hokkaido. Mar Mamm Sci 7:75-84

Watanabe Y (2002) Population genetic studies of Kuril harbor seal (Phoca vitulina stejinegeri) in Hokkaido, Japan, by mtDNA sequences. In: Report on 6th natural environmental preservation base survey sea area natural environmental preservation base survey, Marine mammal survey of the Ministry of the Environment (pinniped and sea otter living survey). Japanese Ministry of the Environment Agency, Yamanashi, p 47-51 (in Japanese)

Westlake RL, O'Corry-Crowe GM (2002) Macrogeographic structure and patterns of genetic diversity in harbor seals (Phoca vitulina) from Alaska to Japan. J Mammal 83: 1111-1126

Submitted: November 1, 2011; Accepted: Octobar 7, 2013 Proofs received from author(s): March 10, 2014 